\title{
Teacher Self-Efficacy within the Context of Socially Disadvantaged Pupils' Education
}

\author{
Anna Petr \\ Šafránková ${ }^{1}$ \\ Karla Hrbáčková
}

\author{
Contact to author \\ 1,2 Tomas Bata University in Zlín \\ Faculty of Humanities \\ nam. T. G. Masaryka 5555 \\ 76001 Zlín \\ safrankova@fhs.utb.cz \\ hrbackova@fhs.utb.cz
}

\section{Kontakt na autora}

1,2 Univerzita Tomáše Bati ve

Zlíně

Fakulta humanitních studií

nám. T. G. Masaryka 5555

76001 Zlín

safrankova@fhs.utb.cz

hrbackova@fhs.utb.cz

Copyright (C) 2016 by authors and publisher TBU in Zlín.

This work is licensed under the Creative Commons Attribution International License (CC BY).

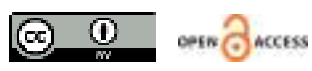

\begin{abstract}
The teachers' self-efficacy (TS) is one of the important determinants, which affects teachers' behavior and also affects the effectivity of educational process. The presented study is based on the concept of Gibson and Dembi, who characterized the teachers' self-efficacy by two dimensions - Personal Teaching Efficacy (PTE) and General Teaching Efficacy (GTE). Our goal is to present results of the research which was focused on determination of the relation between teachers' self-efficacy and the factors related with the education of socially disadvantaged pupils. Among the mentioned research tool it was used the semantic differential method. We found out that the teachers from the chosen primary schools are more convinced about their abilities to influence pupils' learning and behavior (PTE) and less convinced about the overcoming unfavorable effects of environment through the education (GTE). We also discovered that the teachers' self-efficacy rate from chosen primary schools is not correlated with their experience (with the education of socially disadvantaged pupils) and there is no significant difference between TS and the territory of teachers' work. The self-efficacy rate is strongly correlated with the evaluation of the concepts related with the education of socially disadvantaged pupils.
\end{abstract}

Keywords: teacher self-efficacy, socially disadvantaged pupils, teachers, semantic differential

\section{Vnímaná vlastní účinnost učitelů v kontextu edukace sociálně znevýhodněných žáků}

Abstrakt: Vnímaná vlastní účinnost učitelů (teacher self-efficacy - TS) je jednou z významných determinant, která působí na učitelovo jednání a zpětně tak ovlivňuje efektivitu vzdělávacího procesu. Překládaná studie vychází z konceptu Gibsona a Dembiho, kteří charakterizovali vnímanou vlastní účinnost učitelů na základě dvou dimenzí - hodnocení vlastních schopností ve vztahu $k$ rozvoji žáka (PTE) a posouzení vlastních potencialit překonat nepříznivé přirozené prostředí žáka (GTE). Našim cílem je prezentovat výsledky výzkumu zaměřeného na zjištění vztahu vnímané vlastní účinnosti učitelů a vybraných faktorů souvisejících se vzděláváním sociálně znevýhodněných žáků. Pro tyto účely jsme vedle zmiňovaného výzkumného nástroje využili metodu sémantického diferenciálu. Zjistili jsme, že učitelé pưsobící ve vybraných základních školách jsou více přesvědčeni o vlastních schopnostech ovlivnit učení a chování žáků (PTE) než 
o tom, že na základě vyučování mohou překonat nepříznivé vlivy prostředí (GTE). Zároveň jsme zjistili, že míra vnímané vlastní účinnosti učitelů působících ve vybraných základních školách nezávisí na zkušenosti učitelů se vzděláváním sociálně znevýhodněných žáků a výrazně se neliší v závislosti na tom, v jakém kraji učitelé působí. Míra vnímané vlastní účinnosti je výrazně spojená s hodnocením pojmových indikátorů vztahujících se ke vzdělávání sociálně znevýhodněných žáků.

Klíčová slova: vnímaná vlastní účinnost učitele, sociálně znevýhodnění žáci, učitelé, sémantický diferenciál

\section{Introduction}

Socially disadvantaged pupils ${ }^{12}$ education is being currently discussed mainly within the context of inclusive education with the accent on all players in the school environment. As prism of inclusive education and paradigm according to Rogers (Kirschenbaum \& Henderson, 1989, p. 225) an unreserved positive accepting of each pupil (disregarding his/her handicap or disability), both by schoolmates and teachers, appears to be significant. This means in practice that every teacher should accept diversities and specifics of all pupils and guide pupils retrospectively towards this respectful behaviour. $^{13}$

Considering the above mentioned and the fact that a teacher jointly forms education environment, classroom climate, organizes and coordinates activities of pupils, manages and evaluates the teaching process and its results (Průcha et el., 2009, p. 326), discussions relating to teacher's profession as one of significant factors of educating pupils occur logically in the conceptual and research field (see also Starý et al., 2012, p. 9). And thus, teacher's influence, teaching, attitudes towards pupils, work with pupils and teacher's self-efficacy (Průcha et al., 2009, p. 326) are besides family environment an important factor, which affects learning of pupils and their school results.

So, it can be claimed that self-efficacy or as the case may be the way how a teacher evaluates and perceives himself/herself as a teacher and has beliefs about himself/herself is one of significant determinants of teacher's efficacy (in addition to his/her qualification, personality traits, competences and others) within his educating activities. Teacher's perceived self-efficacy can be understood within this context as a catalyst or inhibitor of teacher's positive behaviour in relation to his/her education activities (Gavora, 2008; Ross, 1994), a factor that can affect school results of pupils (e.g., Ashton \& Webb, 1986; Gibson \& Dembo, 1984; Ross, 1992; Tschannen-Moran et al., 1998), perceived self-efficacy of pupils (Anderson et al., 1988) and a level of pupils' motivation (Midgley et al., 1989). Researches also prove that teachers with a high level of perceived self-efficacy tend to apply new approaches and methods to education, use methods supporting autonomy of pupils and tend to support pupils in need of individual support (Guskey, 1988, Gillnerová et al., 2011; Ross, 1994;). Similarly, Buel et al. (1999) discovered within his research a relation between teachers' self-efficacy and his/her attitude towards educating pupils with special education needs. Teachers with higher self-efficacy perceive pupils' diversity positively and they are as well self-confident to

12 For the purposes of this study we consider socially disadvantaged, as pupils coming from a family who, because of its socioeconomic and cultural conditions insufficiently encourages or insufficiently allows, or completely disallows the mental, emotional and volitional characteristics of the child and which is socioeconomically and culturally different from the environment in which pupils coming from the majority population grow up in. This difference significantly impedes their full-fledged participation in society and from fully developing their educational potential. (Šafránková \& Kocourková, 2013a).

13 Dewey's words (as cited in Kirschenbaum \& Henderson, 1989, p. 225) that acceptance should not be dependent on a selective evaluation attitude: "You are wrong in this, but in this you're good." 
manage hard situations and demands at educating this specific group of pupils. On the contrary, teachers with lower self-efficacy may not perceive pupils' diversity positively (e.g., since they do not feel to be competent adequately) (see also Bender et al., 1995).

In consideration of the above mentioned and based on other researches (e.g., Brownell \& Pajares, 1999) we can deliberate over relation between teacher's self-efficacy and his/her attitude towards certain group of pupils (in case of the submitted study towards socially disadvantaged pupils), who need special attention in terms of use of compensating measures, specific forms, teaching methods and others.

The study submitted is focused on determining the teachers' self-efficacy in selected regions and determining, whether there is a relation between teachers' self-efficacy and length of educational experience, age, region, where teachers are employed, experiences in educating socially disadvantaged pupils and further perception of selected conceptual indicators that relate to education of socially disadvantaged pupils.

Sense of self-efficacy can be understood within a wider concept, the so-called teachers' beliefs, which Bandura (1997) names as a factor affecting individual's activities. In addition to the teacher self-efficacy we can find teachers' beliefs about pupils within this concept (e.g., Brownell \& Pajares, 1999). Within this concept, we can deliberate over relation between teachers' self-efficacy and their attitude towards socially disadvantaged pupils. Even though the mentioned researches prove that due attention has been already paid to the area of teachers' self-efficacy in relation to various aspects of education, researches focused on relation between teacher self-efficacy and teachers' beliefs about socially disadvantaged pupils belong rather to the rare ones. We consider this connection as a significant research topic, since we work on the assumption that teacher self-efficacy can be associated with teacher's beliefs about certain group of pupils. Besides other things it can affect activities of a teacher in relation to this group of pupils retrospectively and further not only the quality of education process, but also efficacy of inclusive education in general or as the case may be teacher's self-efficacy can be conceived to be a predictor of his/her thought and actions.

\section{Theoretical framework of self-efficacy}

The concept of self-efficacy as beliefs about personal qualities to achieve defined output level, affected by events in our lives (see also Ardelt \& Eccles, 2001; Bandura, 1994), was elaborated for the first time by Albert Bandura (1977) within social-cognitive theories. This theory is a framework for understanding and explanation of human behaviour (Gillernová et al., 2011, p. 154). Social-cognitive theories accent various aspects of social-cultural transactions between a human and his/her environment (Bertrand, 1998, p. 117). A model of triadic reciprocal determinism, which is built against one-sided interpretation of behaviour based only on effects of one determinant or as the case may be environment or inner dispositions, is the centre of this theory. This model consists of three factor groups (personal qualities, behaviour and social environmental effects), which are connected one with another and integrate together. Janoušek (1992, p. 386) states that determinism is conceived as a resultant effect of an aggregate of interconnected influences, which is perceived within this meaning rather as probable than linear. Bandura (1997) expects based on the mentioned model that individuals are not quite free and they are affected by the environment, nevertheless they are not subjected to environmental effects passively or as the case may be individuals are perceived as proactive and self-regulating human beings capable of their own organization and views. Bandura (as cited in Janoušek, 1992, p. 389) names the moment of self-influencing of mutually interacting determinants as the term "self-efficacy".

According to Bandura $(1997$, p. 2) the concept of self-efficacy is based on the fact that the level of human motivation and behaviour is rather based on in what individuals believe (on their beliefs) than on their objective qualities. And thus, beliefs about self-efficacy are the base how people feel and 
think and it is associated closely with motivation, since beliefs about self-capacities obviously affect expectations with respect to future behaviour. (Bandura, 1994; Pajares, 2002) Strong sense of selfefficacy affects the way how individuals approach to demanding tasks, which they take rather like a challenge than a threat (Bandura, 1994). Some authors (Gillnerová et al., 2011; Rutter, 1990; Tedeschi \& Calhoun, 1995) name it a relation between self-efficacy and ressilience of an individual. It can be claimed in general that a high level of self-efficacy results in setting of demanding targets, making effort to achieve them, smaller probability to be beaten by stress, controlling own emotional states and also in active approach to hardship (Bandura, 1994; Gillnerová et al., 2011). On the contrary, individuals with a low level of self-efficacy have doubts about their qualities, they tend to be beaten by stress, attempt to avoid demanding tasks, since they take them as a threat, and their aspirations are low like their resolve to achieve these tasks (Bandura, 1982, 1994; Gillnerová et al., 2011, Pajares, 2002). Beliefs about self-efficacy consist according to Bandura (1994) of four main sources: 1. Experience of success at managing an unfavourable situation (or as the case may be positive experience); 2 . Social modelling, i.e. mediated vicarious experience of others at managing given situation; 3 . Social persuasion (verbal support from others, beliefs about abilities to manage given situation); 4. Physiological and emotional states of the teacher.

According to the above mentioned facts the self-efficacy can be considered within the context of social-cognitive theories as a significant determinant, which can have effect on teacher's activities and affect educating of pupils retrospectively. We focus more particularly on teacher's sense of selfefficacy for purposes of the study submitted.

\subsection{The nature of teacher self-efficacy}

Teacher's beliefs about his/her professional qualities and skills or as the case may be how he/she evaluates himself/herself in terms of his/her profession appear to be significant besides professional qualities and skills that characterize the teacher in relation to his/her education work. So, teacher's sense of self-efficacy can be also defined as his/her beliefs about his/her qualities that result in achieving required (positive) outcomes in the area of involvement and learning, specifically also of students, who show a lower level of motivation and who need specific individual support (Armor et al., 1976; Bandura, 1977). A significant factor affecting teacher's behaviour in various education situation is concerned, specifically reflecting into teacher's beliefs about how he/she acts on pupils and what education output he/she can achieve (Gavora, 2008).

A teacher with high self-efficacy approaches to his/her education work with beliefs about his/her professional knowledge, qualities and skills, and therefore he/she makes more effort during preparation and realization of teaching (Gibson \& Dembo 1984; Tschannen-Moran et al., 1998). These teachers perform their education work with beliefs that with making special effort, effective teaching and with application of special techniques, which can include also support of family, ${ }^{14}$ negative effects of community on a child can be prevented (Gillnerová et al., 2011, p. 156). On the contrary, teachers with low self-efficacy attempt to avoid demanding situations and if such situation occurs teacher does not have beliefs about his/her capabilities to manage such situation adequately (Mareš, 2013). These teachers believe that regardless of making more effort they can do only a little, if pupils are not motivated (Gillnerová et al., 2011, p. 156). Low self-efficacy can become evident in his/her aggressive behaviour (motivated by fear to fail), but also in quitting his/her attempt at improving school results of pupils, who do not achieve the required school results in short time period $^{15}$ (Gibson \& Dembo, 1984).

In general, it can be claimed concerning teacher self-efficacy that: 1 . it is formed by teacher himself/herself (i.e. it is not a priori given, it is formed already during pre-gradual preparation and continues to develop with exercise of teacher's practice; 2 . it can acquire different level; 3 . it

14 Cooperation with family is quite significant in education of socially disadvantaged individuals.

15 In this case it is concerning e.g. socially disadvantaged pupils. 
functions rather functionally (teacher may not always come to realize it and analyse it; 4 . it is constant relatively, i.e. even though changes can occur based on many factors, it does not change quickly only based on certain occasional situations; 5 . it can be investigated at teachers with various orientations, taught subjects and others. (or as the case may be it is conditioned by situation) (Gavora, 2008; Ross \& Bruce, 2007; Tschannen-Moran et al., 1998; Wertheim \& Leyser, 2002).

Teacher self-efficacy became a subject of a lot of researches (see e.g., Klassen et al., 2011). Researches of self-efficacy apply both the research qualitative strategy (e.g., Cantrell \& Callaway, 2008; Cheung, 2008; Milner \& Woolfolk Hoy, 2003; Onafowora, 2005; Webb \& Ashton, 1987) and the quantitative research strategy (Gavora, 2008, 2010, 2011; Gibson \& Dembo, 1984; Greger, 2011; Guskey \& Passaro 1994; Tschannen-Moran et al. 1998). Teacher Efficacy Scale - TES, from Gibson and Dembo and others (1984), became one of frequently used research tools (also used for our research). This research tool originally consisted of 30 statements that were assessed by teachers on the six-point Likert's scale (from strongly disagree to strongly agree). Two factors were extracted based on the factor analysis: 1 . Teacher's beliefs about his/her qualities (Personal Teaching Efficacy - PTE) i.e. teacher's beliefs about his/her qualities to affect learning and behaviour of pupils; 2. Potentiality of teaching perceived by a teacher (General Teaching Efficacy) i.e. teacher's beliefs about his/her qualities to overcome or reduce adverse external factors, which could affect educating of pupils (e.g., non-stimulating family environment of a pupil) (Gibson \& Dembo, 1984).

According to the above mentioned facts teacher self-efficacy can be a significant determinant, which can have positive/negative effect on educating of pupils, who come from socially disadvantaged family environment, since just teacher's beliefs about socially disadvantaged pupils and about his/her self-efficacy have effect on teacher's education work in relation to the group of pupils mentioned.

\section{Research survey}

The study submitted presents results of realized research, of which target was to determine the level of self-efficacy (Teacher Self-Efficacy) of teachers (TS) at primary schools in selected regions. We were interested in how teachers assess the level of self-efficacy in the area of potentiality of teaching perceived by a teacher (General Teaching Efficacy) and teacher's beliefs about his/her qualities (Personal teaching Efficacy), i.e. up to what extent it is possible in view of a teacher to overcome or at least reduce adverse factors not on the teacher's side based on teaching, for example poor abilities of a pupil, unfavourable family environment of a pupil (GTE), and up to what extent a teacher believes in his/her abilities to have influence on learning and behaviour of pupils (PTE).

We focused on finding differences in teachers' self-efficacy (TS) in selected regions, where they are employed. These regions were selected based on social-demographic analysis according to the level of social disadvantage. We assumed that the perceived self-efficacy, in particular teachers' beliefs about possibilities to overcome unfavourable pupil's environment (GTE), would manifest itself differently in a region with a higher rate of endangered children. We were also interested in what is the relation between the teachers' self-efficacy and length of their education practice, age and experiences in educating socially disadvantaged pupils. This experience can be reflected significantly into the teacher's self-efficacy. Considering the fact that the self-efficacy is according to Bandura (1994) based on four primary sources (1. positive experience in managing a situation; 2 . vicarious experiences mediated by means of social models; 3 . social persuasion; 4. opinion on self-condition) and it can be changed in the course of individual's life, experiences and professional career. We were investigating during our research a relation between GTE/PTE and perception of selected conceptual indicators that relate to education of socially disadvantaged pupils (socially disadvantaged pupil, 
pupil from a culturally different family environment, inclusion, segregation, our school, me). ${ }^{16}$ We assumed that the perceived level of self-efficacy was associated with assessment of selected terms that relate to education of socially disadvantaged pupils, in particular teacher's beliefs whether he/she can overcome unfavourable pupil's environment (GTE). This connection can manifest itself differently in significance (factor) of assessment (whether assessment of positive/negative significance of given term is concerned, i.e. factor of evaluation, or whether an assessment connected with making certain effort/energy to achieve a change, i.e. energy factor, is concerned).

\subsection{Research questions}

Our research was focused on answering the following questions:

1. What is the level of perceived teachers' self-efficacy employed in selected primary schools?

2. What are the differences in teachers' self-efficacy dependent on a region, where they are employed? What is the difference in teachers' self-efficacy employed in the Central Bohemia region, Vysočina region and Moravian-Silesian region in the area of potentiality of teaching perceived by a teacher (GTE) and teacher's beliefs about his/her qualities (PTE)?

3. What is the relation between the perceived teachers' self-efficacy and length of their education practice, age and the fact whether they have experiences in educating socially disadvantaged pupils?

4. What is the relation between perceived teachers' self-efficacy and their assessment of selected conceptual indicators that relate to education of socially disadvantaged pupils?

\subsection{Methods}

The research set was formed by teachers in selected regions (Central Bohemia region, Vysočina region, Moravian-Silesian region) employed according to the international standard classification of education ISCED 1 and ISCED 2 (or more precisely at primary schools). Considering the research purpose and multi-dimensional character of social handicap (determining environment) regions were selected intentionally and selection was performed based on social-demographic analysis (SocioFactor s.r.o., 2013, p. 429). ${ }^{17}$

We selected based on this analysis three regions, which report the smallest, average and highest level (stated below in order) of children in danger from view of the above mentioned dimensions. The following regions are concerned: Central Bohemia region, Vysočina region and Moravian-Silesian region. Due to our attempt to capture specifics of common primary schools, church's schools, special, alternative and international schools were not included into selection. Request to fill in a questionnaire was addressed to all directors of primary schools in selected regions with appeal to transmit information to teachers at the given school. Addresses of directors of these schools were found in a directory of schools and school facilities maintained by the Ministry of School, Youth and Sports.

16 When we are talking about the evaluation of the term "socially disadvantaged pupil", in the text there is always emphasized that it is only the evaluation of the term. While evaluating all presented terms and in the context of education of the concrete group we talk about the education of the socially disadvantaged pupils (more precisely, the relation between the term "socially disadvantaged pupil" and the specification of the education of socially disadvantaged pupils is subordinant, where the term is part of bigger unit).

17 In the Czech environment the analysis focusing on the socio-economic background of pupils occur rather infrequently ("Rovný Prístup," 2014, p. 41). That analysis (Socio-demographic analysis - mapping the distribution of vulnerable children and families in the Czech Republic) examines the area in terms of three dimensions: demographic and social environment; economic activity, unemployment; incompleteness of family and malfunction of the family and its threats. 
Research file consisted of 245 teachers ( 204 women and 41 men), out of it 105 from the Central Bohemia region, 76 from the Moravian-Silesian region and 64 teachers from the Vysočina region. Teachers within the range of age from 40 to 59 years (159 teachers in total) were most represented. The least represented group included teachers under the age of 25 years ( 5 teachers) and teachers above the age of 60 years (14 teachers). The biggest group included teachers having experiences of above 21 years (120 teachers), on the contrary the smallest group included teachers, who are employed for their first year ( 8 teachers) or teachers having experiences of 1-2 years (8 teachers). The research file consists of 177 teachers, who had experiences (during the past ten years) in education of socially disadvantaged pupils, and 68 teachers, who did not have this experience. We do not consider this research to be representative and results address only the selected set of teachers.

Questioning method and semantic differential methods were applied for the purposes of this survey. In order to determine teacher's self-efficacy a questionnaire Teacher Self-efficacy Scale from Gibson and Dembi (1984) was used and adapted and translated to the Czech education environment by Greger (2011). It is a self-evaluating tool, by means of which teachers express their beliefs about their abilities to solve certain teaching situations. We came from 16 -item questionnaire ${ }^{18}$ divided into two factors (PTE and GTE) during the research survey. A teacher rated his level of consent with given characteristics on 6-point scale from "strongly agree" (6) to "strongly disagree" (1), this means the higher point score is, the higher self-efficacy is. Received data were subjected to factor analysis with the application of the method of main components and rotated solution (Direct Oblimin). Four items were rejected due to low value of communality and/or high factor load in both factors (items No. 6 , 7,8 and 15). We used 12 items from the original 16 items. With application of the factor analysis we confirmed that 12 items were decomposed into two factors, which corresponded with the area PTE and GTE. Two extracted factors explain 53.95\% variance. Factor 1 includes 7 items with a factor load from .77 to .62 and explains $32.97 \%$ variance. This factor corresponds with the PTE area (teacher's beliefs about his/her qualities), which determines beliefs in their ability to bring about positive pupils and learning outcomes to have positive effect on learning and behaviour of pupils. Factor $\mathbf{2}$ includes 5 items with a factor load from .84 to .65 and explains $20.98 \%$ variance. All these items are reversible. This factor corresponds with the GTE area (potentiality of teaching perceived by a teacher), which is focused on general findings, up to what extent in teacher's view teaching can overcome unfavourable environmental effects and characteristics of pupils (lack of motivation, nonstimulating family environment and the like). Cronbach's alpha reaches the value $\alpha=.76$ for all 12 items, which indicates mean strong inner consistency. Factor 1 (PTE) achieves high inner consistency $\alpha=.85$, factor 2 (GTE) can be also considered as inner consistent $(\alpha=.78)$.

In order to determine how teachers perceive individual selected indicators relating to education of socially disadvantage pupils, the method of semantic differential was applied. This method is characterized with linking psycholinguistics, psychology of sensing and psychology of individual cognizance together (Maršálová \& Mikšík, 1990, pp. 294-300). This method was developed by Osgood based on many analyses. They came from the assumption that a certain object conceals both the denotative content and connotative content to an individual (Osgood, 1975, pp. 320-321). Respondents were recording their cognizance of terms under assessment (socially disadvantaged pupil, pupil from culturally different family environment, inclusion, segregation, our school, me $)^{19}$ on

18 The original questionnaire TES made by Gibson and Dembi (1984) was consisted of 30 items. Nevertheless, for better quality in terms of educational measurements, it was reduced at 16 items (Henson, 2001).

19 The term of socially disadvantaged pupil (according to school legislation valid until 31. 8. 2016) and pupil from a culturally different environment were chosen with respect to the investigated problem and with respect to as possible close determination of these terms. Attention has been already paid to the term socially disadvantaged pupil in this study (see above) a pupil from culturally different family environment means according to the Czech education policy ("Rámcový vzdělávací," 2013) an individual from various minorities living in our country, with dissimilar ethnic and nationality origin, or possibly a pupil who came to our country within migration (in particular a recognised refugees or asylum-seekers). The terms inclusion and segregation are understood also in compliance with the Czech education policy (see, for example, 
7-point scale, formed by opposite adjectives. We applied the 2-factor semantic differential - ATER (Attitudes towards Educational Reality) (Chráska, 2007, p. 221). Usually three factors are observed for each term - factor of evaluation, factor of potency and factor of activity, which form a threedimensional semantic space (Chráska, 2007, p. 221). In view of the fact that factors of evaluation and energy ${ }^{20}$ characterize significance, which we intended to investigate in relation to the issue of education of socially disadvantaged pupils (i.e. individual significance of selected conceptual indicators). That is why we worked with these two factors (see also Chráska, 2007). Bipolar scales of individual factors were drawn from the original Osgood's list, which quotes Chráska (2007, pp. 223$224)$ in Czech version. Bipolar adjectives clean - dirty; weak - strong related to 10 bipolar scales (ATER) were completed based on previous researches (e.g., Hladík, 2010; Šafránková \& Kocourková, 2013b). In total, we worked with 12 bipolar scales (see below). Factor of evaluation (in conformity with Osgood, 1975; Chráska, 2007) expresses up to what extent the term under assessment is perceived by respondents as "good" (1) or "bad" (7). Higher value in the given factor expresses more negative assessment of selected term (pleasant - unpleasant, clean - dirty, beautiful - ugly, bright dark, good-bad, sweat-sour). Factor of energy in the area of measuring of education reality shows a relation of term with movement and changes (Chráska, 2007, p. 221). Higher value in the given factor expresses assessment associated with lower movement towards change. On the contrary, lower value represents assessment associated with expending more energy towards change (demanding - undemanding, difficult - easy, strict - lenient, troubled - problem-free, weak - strong, heavy - light). Factor analysis with rotation VARIMAX ${ }_{\text {norm }}$ was used to verify constructional validity of scales. It was found out that factor 1 (evalution) included 6 bipolar scales with a factor load from .42 to .86. and factor 2 (energy) included 6 bipolar scales with a factor load from .41 to .93. Reliability was determined with the use of Cronbach's alpha and reached the value $\alpha=.70$.

We used descriptive statistics (mean value and standard deviation) in order to determine a level of perceived teachers' self-efficacy (and perceived level of teachers' self-efficacy in areas of perceived efficacy). Using the one-factor analysis of variance (ANOVA) we investigated the differences in the teachers' self-efficacy depending on the region where teachers work. We applied the independent samples t-test to discover what are the differences in perceived level of teachers' self-efficacy dependent on teachers' experiences in education of socially disadvantaged pupils. We verified relation between the perceived level of teachers' self-efficacy, length of their education practice and age of teachers, as well as connection of perceived level of teachers' self-efficacy with assessment of selected conceptual indicators that relate to educating socially disadvantaged pupils, with the Pearson's correlation coefficient. Testing was performed in the IBM SPSS Statistics (V21.0.0) program.

\subsection{Research survey results}

The level of perceived teachers' self-efficacy (TS) employed at selected primary schools (table below) reaches an average value $M=3.67$ points, SD $=.44$ (on the 1-6 scale). Their assessment of self-efficacy is slightly above the mean value. Teachers tend to think that they can rather influence learning and behaviour of pupils.

Teacher's beliefs about his/her capabilities (PTE) show a higher average value ( $M=4.06, S D=.60$ ) than teacher's perception of potentiality of teaching (GTE), which reaches an average value $M=$

"Strategie Vzdělávací Politiky," 2014; “Akční plán inkluzivního," 2016). We were also interested within the context of perception of semantic closeness of individual terms in how teachers perceive the term me and our school or as the case may be terms, which are more closely linked to the teacher's profession and personality.

20 Our research is based on the research tool ATER in which the factor of energy is considered in the link with the factor of activity and potency (it means, it is analogous to mechanical energy = potential energy + kinetic energy). In this context the energy factor indicates the extent to which respondents have given the term associated with exertion, difficulties or changes activity (Chráska, 2007, p. 228). 
3.14, SD $=.79$. Teachers' beliefs about his/her capabilities to influence learning and behaviour of pupils (PTE) are higher than general teachers' conviction of possibility to overcome or reduce adverse environment effects (GTE). We can observe that this general conviction is slightly under a mean value, which means that teachers on average rather do not agree that based on teaching they can overcome adverse factors laying outside them (GTE).

Table 1

Level of perceived teachers' self-efficacy at selected primary schools

\begin{tabular}{lcccc}
\hline Self-efficacy & Minimum & Maximum & Mean & SD \\
\hline GTE & 1.00 & 6.00 & 3.14 & .79 \\
PTE & 1.00 & 6.00 & 4.06 & .60 \\
TS & 2.42 & 5.00 & 3.67 & .44 \\
\hline
\end{tabular}

We can observe (table below) at the same time that assessment of teacher's self-abilities to influence learning and behaviour of a pupil (PTE) correlates with teacher's conviction of possibilities to overcome adverse environment effects (GTE). This means that the higher teacher's conviction of his/her own abilities to influence learning and behaviour of pupils (PTE) is, the lower their conviction of possibilities to overcome or reduce adverse environment effects (GTE) is and the other way around $(r=-.16, p<.05)$.

Table 2

Connection between teacher's conviction of his/her own abilities (PTE) and conviction of possibility to overcome adverse environment effects (GTE)

\begin{tabular}{lcc}
\hline Self-efficacy & PTE & GTE \\
\hline PTE & - & - \\
GTE & $-.16^{*}$ & - \\
\hline
\end{tabular}

Note. ${ }^{*}=$ Differences are significant at the .05 level.

Perception of teachers' self-efficacy (TS) in selected regions is not different significantly in terms of statistics $(p=.94)$. Selected teachers show a similar level of self-efficacy (table below) in the Central Bohemia region, Vysočina region and Moravian-Silesian region. Mean values are within the range from $M=3.66$ to $M=3.68$ points. Teachers at selected schools in the Moravian-Silesian region, Vysočina region and Central Bohemia region perceive the level of self-efficacy in the area of potentiality of teaching (GTE) $(p=.20)$. Average values are within the range from $M=3.04$ to $M=3.24$ points, which indicates that teachers in all three regions on average rather disagree that their teaching can overcome adverse external factors. Average values of teacher's conviction of his/her abilities (PTE) reach values from $M=3.99$ to $M=4.10$ points in all three regions. In contrast to the level of self-efficacy in the area of potentiality of teaching (GTE) teachers' conviction of own abilities (PTE) is higher at selected schools this conviction of selected teachers does not differ in terms of statistics in individual regions $(p=.42)$.

Table 3

Perception of teachers' self-efficacy in selected regions

\begin{tabular}{lllllll}
\hline & GTE & \multicolumn{3}{c}{ PTE } & & \\
\cline { 2 - 7 } Selected regions & Mean & SD & Mean & SD & Mean & SD \\
\hline Central Bohemia region & 3.24 & .73 & 3.99 & .54 & 3.68 & .43 \\
Vysočina region & 3.04 & .97 & 4.10 & .71 & 3.66 & .43 \\
Moravian-Silesian region & 3.08 & .69 & 4.10 & .57 & 3.67 & .47 \\
\hline
\end{tabular}

The level of perceived self-efficacy (TS) correlates positively with age of teachers at selected schools $(r=.14, p=.03)$ and also with length of their education practice $(r=.15, p=.02)$. The level of 
teachers' self-efficacy (TS) employed at selected primary schools (table below) is increasing together with age and length of education experience.

Table 4

Relation between perceived teachers' self-efficacy, length of their education experience and age of teachers at selected primary schools

\begin{tabular}{llll}
\hline Selected variables & TS & Age & Experience \\
\hline TS & - & $.14^{*}$ & $.15^{*}$ \\
Age & & - & $.82^{* *}$ \\
Experience & & & - \\
\hline
\end{tabular}

Notes. * Differences are significant at the .05 level. ${ }^{* *}=$ Differences are significant at the .01 level.

The level of perceived teachers' self-efficacy (TS) employed at selected primary schools is not dependent, whether a teacher had experience (during the past ten years) in educating socially disadvantaged pupils $(p=.27)$. Teachers, who had experience in educating socially disadvantaged pupils, perceive their self-efficacy $(T S)$ like $(M=3.65, S D=.44)$ teachers, who do not have this experience $(M=3.72, S D=.42)$. Teachers' experiences in educating socially disadvantaged pupils do not show in individual areas of self-efficacy (PTE/GTE). Beliefs about own qualities to have positive impact on pupils' results (PTE) achieve a comparable level $(p=.97)$ at teachers, who have experience in educating socially disadvantaged pupils $(M=4.06, S D=.64)$, like at teachers, who do not have this experience $(M=4.06, S D=.45)$. Disregarding experience in educating socially disadvantaged pupils teachers are in accord that they do not have such possibilities to overcome adverse environment effects and characteristics of pupils (GTE) based on teaching. Teachers, who have experience in educating socially disadvantage pupils, reach average value $M=3.09(S D=.82)$ and teachers, who do not have this experience, reach average value $M=3.25(S D=.70)$. Differences in assessment of potentiality of teaching to overcome unfavourable family environment of pupils (GTE) are not significant in terms of statistics $(p=.27)$.

Table 5

Differences in perception of teachers' self-efficacy dependent on experience in educating socially disadvantaged pupils

\begin{tabular}{lllll}
\hline Self-efficacy & Experience & Mean & SD & SE \\
\hline \multirow{2}{*}{ GTE } & No & 3.25 & .70 & .09 \\
& Yes & 3.09 & .82 & .06 \\
PTE & No & 4.06 & .45 & .06 \\
& Yes & 4.06 & .64 & .05 \\
TS & No & $\mathbf{3 . 7 2}$ &. $\mathbf{4 2}$ & .05 \\
& Yes & $\mathbf{3 . 6 5}$ &. $\mathbf{4 4}$ & .03 \\
\hline
\end{tabular}

The level of perceived self-efficacy (TS) at selected teachers correlates significantly ${ }^{21}$ with assessment of conceptual indicator of socially disadvantaged pupil $(r=.33, p<.01)$ and with assessment of conceptual indicator pupil from a culturally different environment $(r=.18, p<.01)$. The higher self-efficacy (TS) is, the more positive the teachers' assessment of the term socially disadvantaged pupil and pupil from culturally different environment is (and the other way around). More positive assessment of conceptual indicator socially disadvantage pupil is evident at teachers, who believe that they can overcome adverse pupil's environment through teaching (GTE) $(r=.29$,

21 We kept the line of assessment on the overall rate of perceived self-efficacy (TS) in relation to individual terms and consecutively in partial areas (GTE and PTE) in relation to selected terms at assessing connections between perceived level of teachers' self-efficacy and assessment of selected conceptual indicators relating to education of socially disadvantaged pupils. We intended in particular to capture the level of self-efficacy in relation to assessment of selected terms, not primarily assessment of selected terms. 
$p<.01)$. Assessment of self-abilities in relation to influencing of learning and behaviour of pupils (PTE) is not connected with assessment of the conceptual indicator socially disadvantaged pupil $(r=.12, p=.06)$. On the contrary, there is evident a connection with assessment of self-abilities to influencing of behaviour and learning of pupils (PTE) $(r=.15, p=.02)$ at assessing the conceptual indicator pupil from culturally different environment. Assessment of this term is not connected with teacher's beliefs about possibility to overcome or reduce adverse external factors (GTE) ( $r=.07$, $\mathrm{p}=.31$.

The level of perceived self-efficacy (TS) correlates significantly with the conceptual indicator inclusion $(r=.26, p<.01)$. Assessment of the conceptual indicator inclusion is associated both with assessment of self-abilities to influencing of behaviour and learning of pupils (PTE) $(r=.14, p=.03)$ as well as with teacher's beliefs about possibility to overcome or reduce adverse natural pupil's environment (GTE) $(r=.20, p<.01)$.

Assessment of the conceptual indicator our school $(r=.23, p<.01)$ and the conceptual indicator me $(r=.18, p<.01)$ is associated with the level of perceived self-efficacy (TS). Teachers, who achieve a higher level of self-efficacy (TS), assess at the same time the term me and the term our school more positively. The higher the level of teachers' self-efficacy (TS) is, the more positive their assessment of themselves (the conceptual indicator me) and the term our school is. More positive assessment of the conceptual indicator me and the conceptual indicator our school is evident in case of higher assessment of self-abilities in relation to influencing of a pupil (PTE). Teachers, who believe in their self-abilities to influence learning and behaviour of pupils positively (PTE), assess the conceptual indicator me $(r=.20, p<.01)$ and the conceptual indicator our school $(r=.27, p<.01)$ more positively. Teachers' opinion up to what extent they can overcome through teaching adverse environment effects and characteristics of pupils (GTE) is not associated with assessment of the conceptual indicator me $(r=.02, p=.75)$ nor with assessment of the conceptual indicator our school $(r=.02, p=.82)$.

The level of self-efficacy (TS) is not associated with assessment of the conceptual indicator segregation ( $r=-.07, p=.28)$. The way how teachers assess their self-efficacy (TS) is not reflected into assessment of the term segregation. Assessment of the conceptual indicator segregation is not associated with teachers' beliefs about their own qualities to influence learning and behaviour of pupils (PTE) ( $r=.06, p=.35$ ), but on the contrary it is associated with finding, to what extent (in teacher's opinion) teaching can overcome adverse environment effects and characteristics of pupils (GTE) $(r=-.17, p=.01)$. The more teachers at selected primary schools are convinced that they can overcome or at least reduce adverse factors laying outside teachers (GTE) through teaching, the more negative their assessment of the term segregation is.

Table 6

Connection between perceived teachers' self-efficacy and their assessment of selected conceptual indicators in the factor of assessment

\begin{tabular}{llll}
\hline Conceptual indicators & GTE & PTE & TS \\
\hline Socially disadvantaged pupil & $.29^{* *}$ & .12 & $.33^{* *}$ \\
Pupil from culturally different environment & .07 & $.15^{*}$ & $.18^{* *}$ \\
Inclusion & $.20^{* *}$ & $.14^{*}$ & $.26^{* *}$ \\
Segregation & $-.17^{* *}$ & .06 & -.07 \\
Our school & .02 & $.27^{* *}$ & $.23^{* *}$ \\
Me & .02 & $.20^{* *}$ & $.18^{* *}$ \\
\hline
\end{tabular}

Notes. ${ }^{*}=$ Differences are significant at the .05 level. ${ }^{* *}=$ Differences are significant at the .01 level.

Level of perceived self-efficacy (TS) at selected teachers correlates negatively with assessment of the conceptual indicator socially disadvantaged pupil at the energy factor $(r=-.20, p<.01)$. Teachers with a higher level of perceived self-efficacy (TS) link the term socially disadvantaged pupil 
to a lower level of expended energy. This connection is evident at assessing potentiality of teaching to overcome adverse pupil's natural environment (GTE) $(r=-.26, p<.01)$. The less teachers at selected primary schools believe that they can overcome adverse environment effects and characteristics of a pupil (GTE) through teaching, the more they associate the term of socially disadvantaged pupil with expending energy towards change (effort) (or more precisely the higher teachers' conviction of possibilities to overcome adverse external factors is, the less they associate the term of socially disadvantaged pupil with making some effort). Assessment of self-abilities to influencing of learning and behaviour of pupils (PTE) is not connected with assessment of the conceptual indicator socially disadvantaged pupil $(r=.01, p=.99)$ at the energy factor.

Connection between teachers' self-efficacy (TS) employed at selected primary schools and their assessment of the conceptual indicators pupil from a culturally different environment $(r=-.02$, $p=.81)$, inclusion $(r=-.02, p=.74)$, segregation $(r=.09, p=.16)$, our school $(r=-.02, p=.70)$, me $(r=.02, p=.77)$ was not proved at the energy factor. The way how teachers at selected primary schools assess the level of self-efficacy (whether assessment of self-abilities, behaviour and learning of pupils or assessment of possibilities how to overcome adverse natural pupil's environment is concerned) is not associated up to what extent they associate selected terms (inclusion, segregation, our school, pupil from culturally different environment or me) with attempt or quantity of expended energy.

Table 7

Connection between perceived teachers' self-efficacy and their assessment of selected conceptual indicators in terms of the energy factor

\begin{tabular}{lccc}
\hline Conceptual indicators & GTE & PTE & TS \\
\hline Socially disadvantaged pupil & $-.26^{* *}$ & -.01 & $-.20^{* *}$ \\
Schoolchild from culturally different environment & -.02 & -.01 & -.02 \\
Inclusion & -.07 & .02 & -.02 \\
Segregation & .03 & .12 & .09 \\
Our school & .09 & -.10 & -.02 \\
Me & .04 & .01 & .02 \\
\hline
\end{tabular}

Notes. ${ }^{*}=$ Differences are significant at the .05 level. **= Differences are significant at the .01 level.

\section{Summary and discussion}

Our research was focused on findings what is the relation between perceived teachers' self-efficacy at primary schools and selected factors associated with educating of socially disadvantaged pupils. We found out that teachers employed at selected primary schools believed more in their education capabilities to influence on learning and behaviour of pupils (PTE) than in their possibilities to affect adverse effects of external environment (GTE). Teachers on average rather agree that they have qualities to influence learning and behaviour of pupils (PTE), although they tend to think that based on education they can overcome adverse factors laying outside them (GTE) in lower extent, i.e. lack of motivation, non-stimulating family background of pupils etc. Similarly, teachers achieve higher score in the area of PTE contrary to the area of GTE in a number of other researches, or as the case may be they have beliefs about their education qualities in relation to education and upbringing of pupils than about their possibilities to compensate adverse effects of external environment (e.g., Cerit, 2010; Gavora, 2011; Gavora \& Majerčíková, 2012; Graham, 2011; Gorrell \& Hwang, 1995; Greger, 2011).

It is interesting that the more teachers from selected primary schools are convinced of their own qualities to influence learning and behaviour of pupils (PTE), the less they are convinced that they can overcome adverse environment effects (GTE). It is possible that they come to realize more strongly impact of natural environment of pupils (fundamental impact of family on behaviour and 
learning of pupils), even though they are convinced of their possibilities to influence learning and behaviour of pupils (PTE). We would expect that teachers, who are convinced of their own qualities to influence learning and behaviour of pupils (PTE), are also convinced that they can overcome adverse environment effects (GTE).

Every life period places various demands on abilities to function successfully, which is also reflected into dynamics of perceived teachers' self-efficacy. The level of perceived self-efficacy (TS) correlates positively with age of teachers and also with length of their education practice. It is obvious that the level of teachers' self-efficacy (TS) employed at selected primary schools is increasing together with age and length of education experience. It is not surprising that together with gained experiences (professional and life experiences) their beliefs about self-abilities and their conviction of possibilities to influence learning and behaviour of pupils grow. Education experience can contribute up to certain extent that teachers of selected primary schools have higher certainty (this means that they probably know their possibilities and limits) in that they can affect learning and behaviour of a pupil (see also Bandura, 1994; Ďurkovičová, 2013).

It follows at the same time from the research results that the level of perceived self-efficacy of teachers (TS) employed at selected primary schools is not dependent on teachers' experience in education of socially disadvantaged pupils. Teachers, who have experience in educating socially disadvantaged pupils, perceive their self-efficacy (TS) like teachers, who do not have this experience. Disregarding experience of teachers in education of socially disadvantaged pupils, teachers from selected primary schools have comparable level of beliefs about their own capabilities to influence learning and behaviour of pupils (PTE) and they hold similar view that they rather cannot overcome adverse external effects (GTE) through teaching. It follows indirectly from these results that even though education experience and age of a teacher at selected primary school are to some extent reflected into teacher's beliefs about self-efficacy, this experience does not need to be connected with education of socially disadvantaged pupils. We suppose that experiences, which result from various education situations that teachers solve at the course of their everyday education practice, are concerned. In fact, any experience is reflected into the perceived level of self-efficacy (and it does not need to be connected with education of socially disadvantaged pupil). Conclusions from some researches give evidence that substitute experience and social pressure can have effect on conviction of teachers to overcome adverse external environment effects (GTE) (Watters \& Ginns, 1995) and teacher's beliefs about his/her own abilities to influence learning and behaviour of pupils (PTE) are rather affected by actual education experience (Housego, 1992; Hoy \& Woolfolk, 1990).

It is not surprising in continuity of previous findings that teachers' self-efficacy (TS) does not differ significantly at selected primary schools depending on region, where teachers are employed. Teachers have comparable level of beliefs about their abilities to influence learning and behaviour of pupils (PTE) disregarding whether a region reports the smallest, average or highest level of children in danger in all selected regions (Central Bohemia region, Vysočina region and Moravian-Silesian region). They are in accord that they can overcome in smaller extent adverse environment effects laying outside them (GTE) through teaching. In consideration that experiences in education of socially disadvantaged pupils are not reflected significantly into the level of teachers' self-efficacy we are not surprised that there are not significant differences in teachers' self-efficacy in selected regions with different level of social disadvantage (where this experience can play principal role).

Research results indicate that perceived teachers' self-efficacy at selected primary schools is associated with assessment of conceptual indicators relating to education of socially disadvantaged pupils. This connection (with assessment of conceptual indicators that relate to educating of socially disadvantaged pupils) occurs differently according to what area of perceived self-efficacy is concerned (GTE/PTE) and according to significance (factor) of assessment (whether assessment of positive/negative significance of given term is concerned, i.e. factor of evaluation, or assessment associated with making certain effort/energy towards change, i.e. energy factor, is concerned). Tschannen-Moran, Woolfolk Hoy and Hoy (1998) states that teachers with high level of 
perceived self-efficacy (TS) tend to individual approach towards individuals in need of specific support. However, we can only assume within this context that results of assessment of individual terms by means of a semantic differential can predict willingness/unwillingness of respondents aimed at certain activity ${ }^{22}$. Similarly, Guskey (1984) states that higher level of perceived self-efficacy has effect besides others on positive attitudes towards education.

Perception of teachers' self-efficacy (TS) is associated with assessment of conceptual indicators socially disadvantaged pupil, pupil from culturally different environment, inclusion, our school and conceptual indicator me. This means that the higher level of perceived teachers' self-efficacy at selected primary schools (TS) is, the more positive their assessment of the term socially disadvantaged pupil, pupil from culturally different environment, the term of inclusion, our school and the conceptual indicator is. The level of perceived self-efficacy (TS) is not associated with how teachers from selected primary schools assess the term segregation. Similarly also other researches (e.g., Soodak, Podell, \& Lehman, 1998; Weisel \& Dror, 2006) confirm influence of perceived teacher's self-efficacy on positive/negative attitude towards inclusion.

Teacher's beliefs about possibilities to overcome or reduce adverse pupil's environment (GTE) are associated with assessment of the term socially disadvantaged pupil, of the terms inclusion and segregation. The more teachers at selected primary schools are convinced of possibilities to overcome or reduce adverse external factors (GTE), the more they assess positively the term of socially disadvantaged pupil, the term of inclusion, and asses more negatively the term of segregation. It is not surprising from this view that teachers from selected primary schools are convinced that they cannot influence adverse environment effects and characteristics of a pupil (GTE) through education and they may associate education of socially disadvantaged pupils with unpleasant feelings and negative perception of these pupils.

It turned out that conviction of teachers from selected primary schools of their own qualities to affect learning and behaviour of pupils (PTE) was associated with assessment of the terms pupil from culturally different environment, inclusion, our school and with assessment of himself/herself (the conceptual indicator $m e$ ). The more teachers from selected primary schools are convinced of their own qualities to affect learning and behaviour of pupils (PTE), the more they assess positively the terms pupil from culturally different environment, inclusion, our school and the term me. If a teacher believes in his/her own qualities, there is a probability that he/she associates school, where he/she is employed, with positive assessment and he/she perceives himself/herself positively.

The level of perceived conviction of teachers' self-abilities (PTE) at selected primary schools does not relate to assessment of terms socially disadvantaged pupil and segregation. Perception of the term of segregation is not probably unequivocal and a lot of other factors will play a role. It is obvious that teachers from selected primary schools, who have higher beliefs about their qualities (PTE) perceive differently significance of terms socially disadvantaged pupil and pupil from culturally different environment. Even though teachers are convinced of their own capabilities to influence learning and behaviour of a pupil (PTE), they assess the term of socially disadvantaged pupil differently (both positively and negatively). Their conviction in this regard is not associated with perception of the term of socially disadvantaged pupil. It could occur due to the fact that perception of socially disadvantaged pupils is affected for the most part by other variables, for example education experience, which is connected with teachers' self-efficacy at selected primary schools (TS).

The level of perceived self-efficacy is associated significantly with assessment of conceptual indicators relating to education of socially disadvantaged pupils at the factor of evaluation, i.e. in positive or negative sense. It is then associated in lower extent with assessment of conceptual indicators at the energy factor, i.e. whether teachers associate the term with expending of more or

22 We assume that the method of semantic differential measures the attitudes (consisting of cognitive, emotional and conative components) individuals to a particular concept. 
less energy towards change. This connection appears only at assessing the term of socially disadvantaged pupil (in the GTE area).

Teachers with a higher level of perceived self-efficacy (TS) link the term socially disadvantaged pupil to a lower level of expended energy. This connection appears distinctly in the area of potentiality of teaching (GTE). This means that the lower teachers' conviction of possibilities to overcome adverse external factors (GTE) at selected primary schools is, the more they associate the term of socially disadvantaged pupil with making certain effort. Selected primary school teachers' conviction of possibilities to overcome or reduce adverse effects of family environment (GTE), as well as teachers' beliefs about their own abilities to influence learning and behaviour of pupils (PTE), are not associated at all with assessment of the term of pupil from culturally different environment, inclusion, segregation, our school nor with the conceptual indicator me.

Teachers from selected primary schools associate the terms relating to education of socially disadvantaged pupils with various power intensity (expending energy). Their conviction of their own qualities to influence school results and learning of pupils (PTE) is not associated with whether they connect selected terms with making certain effort.

Teachers' conviction of their own qualities to influence learning and behaviour of pupils is connected with other factors than with perception of significance of terms at the energy factor (certain movement towards change). It is obvious from results that this conviction is rather connected with positive or negative perception of selected conceptual indicators (at the factor of evaluation).

At conclusion, we can claim that perceived teachers' self-efficacy (TS) is connected significantly with all selected terms, apart from the conceptual indicator of segregation. We discover at the same time that perceived teachers' self-efficacy at selected primary schools is connected very significantly with assessment of the conceptual indicator inclusion, where it is obvious that the higher perceived teachers' self-efficacy is (in the area GTE and PTE), the more positive the assessment of the conceptual indicator inclusion is. When we investigate individual areas of perceived self-efficacy in more details, we find out that this connection is present differently in each area (GTE and PTE). The term of socially disadvantaged pupil is connected significantly with up to what extent teachers at selected primary schools have beliefs about their possibilities to overcome unfavourable effects laying outside them (GTE), for example poor abilities of a pupil or unfavourable family environment of a pupil, while the term of pupil from culturally different environment is connected significantly with teachers' beliefs about their own qualities (PTE). The more teachers from selected primary schools are convinced of their own qualities to affect learning and behaviour of pupils (PTE), the more they assess positively the terms pupil from culturally different environment, inclusion, our school and the conceptual indicator me. There is a probability that positive conviction of self-abilities will reflect into positive perception of the term of inclusion, but also into positive assessment of school or himself/herself. On the other side, we can expect positive perception of the term socially disadvantaged pupil at teachers, who are more convinced of possibilities to overcome adverse environment effects (GTE).

We can deduce indirectly from results that teacher's beliefs about himself/herself can be reflected into perception of others in this case pupils, with whom a teacher works, where it is important whether perception of his/her own qualities (PTE) or of possibilities to overcome adverse environment effects (GTE) is concerned. It is obvious from our research that experience in education of socially disadvantaged pupils is not too reflected into perceived teachers' self-efficacy at selected primary schools, nevertheless it cannot be excluded that this experience is reflected into assessment of terms relating to education of socially disadvantaged pupils (at the factor of evaluation), which is closely connected with perceived teachers' self-efficacy. If a teacher is convinced of his/her selfefficacy, then he/she assesses selected conceptual indicators associated with education of socially disadvantaged pupils more positively. According to discovered results and in conformity with Rogers (Kirschenbaum \& Henderson, 1989, p. 225) we believe that besides other things positive acceptance 
and teacher's beliefs about his/her qualities and possibilities to overcome adverse environment effects, which in case of socially disadvantaged pupils can affect their education significantly, are important for successful education of socially disadvantaged pupils.

\section{References}

Akční plán inkluzivního vzdělávání na období 2016-2020. (2016, September 1). Ministry of Education, Youth and Sports (MEYS). Retrieved from http://www.vzdelavani2020.cz/images_obsah/dokumenty/apiv_2016_2018.pdf

Anderson, R. N., Greene, M. L., \& Loewen, P. S. (1988). Relationships among teachers' and students' thinking skills, sense of efficacy, and student achievement. The Alberta Journal of Educational Research, 34, 148-165.

Ardelt, M., \& Eccles, J. (2001). Effects of mother's parental efficacy beliefs and promotive parenting strategies on inner-city youth. Journal of Family, 22(8), 944-72. doi:10.1177/019251301022008001

Armor, D., Conroy-Oseguera, P., Cox, M., King, N., McDonnell, L., Pascal, A., ... Zellman, G. (1976, August). Analysis of the school preferred reading programs in selected Los Angeles minority schools. RAND Corporation. Retrieved from https://www.rand.org/content/dam/rand/pubs/reports/2005/R2007.pdf

Ashton, P. T., \& Webb, R. B. (1986). Making a difference: Teachers' sense of efficacy and student achievement. New York: Longman.

Bandura, A. (1977). Self-efficacy: Toward a unifying theory of behavioral change. Psychological Review, 84(2), 191-215.

Bandura, A. (1994). Self-efficacy. In V. S. Ramachaudran (Ed.), Encyclopedia of human behavior (Vol. 4, pp. 71-81). London: Elsevier, Inc. doi:dx.doi.org/science/article/pii/B9780123750006090030

Bandura, A. (1997). Self-efficacy: The exercise of control. New York: Freeman.

Bandura, A. (1982). Self-efficacy mechanism in human agency. American Psychologist, 37(2), 122147. doi:10.1037//0003-066x.37.2.122

Bender, W. N., Vail, C. O., \& Scott, K. (1995).Teachers' attitudes toward increased mainstreaming: implementing effective instruction for students with learning disabilities. Journal of Learning Disabilities, 28(2), 87-94. doi:10.1177/002221949502800203

Bertrand, Y. (1998). Soudobé teorie vzdělávání. Praha: Portál.

Brownell, M. T., \& Pajares, F. (1999). Teacher efficacy and perceived student success in mainstreaming students with learning and behavior problems. Teacher Education and Special Education, 22(3), 154-163. doi:10.1177/088840649902200303

Buell, M. J., Hallam, R., Gamel-Mccormick, M., \& Scheer, S. (1999). A survey of general and special education teachers' perceptions and inservice needs concerning inclusion. International Journal of Disability, Development and Education, 46(2), 143-156.

Cantrell, S. C., \& Callaway, P. (2008). High and low implementers of content literacy instruction: Portraits of teacher efficacy. Teaching and Teacher Education: An International Journal of Research and Studies, 24(7), 1739-1750. doi:10.1016/j.tate.2008.02.020

Cerit, Y. (2010). Teacher efficacy scale: The study of validity and reliability and preservice classroom teachers' self efficacy beliefs. Journal of Theory and Practice in Education, 6(1), 68-85.

Cheung, H. Y. (2008). Teacher efficacy: A comparative study of Hong Kong and Shanghai primary inservice teachers. Australian Educational Researcher, 35(1), 103-123. doi:10.1007/BF03216877 
Chráska, M. (2007). Metody pedagogického výzkumu. Praha: Grada.

Ďurkovičová, S. (2013). Úroveň profesijnej zdatnosti vnímanej študentmi špeciálnej pedagogiky [PreService Educational Teacher's Self-Efficacy]. Pedagogika.sk, 4(4), 299-320.

Gavora, P. (2008). Profesijná zdatnost' vnímaná učitel'om. Adaptácia výskumného nástroja. Pedagogická revue, 50(3-4). Retrieved from http://www.emetodologia.fedu.uniba.sk/kapitoly/ziskanie-hodnotnych-dat/adaptacia-vyskumnehonastroja.pdf

Gavora, P. (2010). Slovak pre-service teacher self-efficacy: Theoretical and research considerations. The New Educational Review, 21(3), 17-30.

Gavora, P. (2011). Measuring self-efficacy of in-service teachers in Slovakia. Orbis Scholae, 5(2), 7994.

Gavora, P., \& Majerčíková, J. (2012). Vnímaná zdatnost' (self-efficacy) učitela: oblast vyučovania a oblast' spolupráce s rodičmi [Teacher self-eficacy in instruction and in parent involvement]. Pedagogická orientace, 22(2), 205-221. doi:10.5817/PedOr2012-2-205

Gibson, S., \& Dembi, M. (1984). Teacher efficacy: A construct validation. Journal of Educational Psychology, 76(4), 569-582.

Gillernová, I., Kebza, V., \& Rymeš, M. (2011). Psychologické aspekty změn v české společnosti: Člověk na prelomu tisíciletí. Praha: Grada.

Gorell, J., \& Hwang, Y. (1995). A study of efficacy beliefs among preservice tea-chers in Korea. Journal of Research and Development in Education, 28(2), 101-105.

Grahan, S. (2011). Self-efficacy and academic listening. Journal of English for Academic Purposes, 10(2), 113-117. doi:10.1016/j.jeap.2011.04.001

Greger, D. (2011). Jak čeští učitelé hodnotí vlastní efektivitu? Adaptace zahraničního dotazníku. Referát na konferenci ČAPV, Brno.

Guskey, T. R. (1984). The influence of change in instructional effectiveness upon the affective characteristics of teachers. American Educational Research Journal, 21(2), 245-259.

Guskey, T. R. (1988). Teacher efficacy, self-concept, and attitudes toward the implementation of instructional innovation. Teaching and Teacher Education, 4(1), 63-69. doi:10.1016/0742051X(88)90025-X

Guskey, T. R., \& Passaro, P. D. (1994). Teacher efficacy: A study of construct dimensions. American Educational Research Journal, 31(3), 627-643. doi:10.3102/00028312031003627

Henson, R. (2001, January 21). Teacher self-efficacy: Substantive implications and measurement dilemmas. University of Kentucky. Retrieved from http://www.uky.edu/ eushe2/Pajares/EREkeynote.PDF

Hladík, J. (2010). Konstrukce a modely multikulturních kompetencí [Construction and models of multicultural competences]. Pedagogická orientace, 20(4), 27-47.

Housego, B. (1992). Monitoring student teachers' feelings of preparedness to teach, personal teaching efficacy, and teaching efficacy in a new secondary teacher education program. Alberta Journal of Educational Research, 38(1), 49-64.

Hoy, W. K., \& Woolfolk, A. E. (1990). Socialization of student teachers. American Educational Research Journal, 27(2), 279-300. doi:10.3102/00028312027002279

Janoušek, J. (1992). Sociálně kognitivní teorie Alberta Bandury. Českosloveská psychologie, 36(5), 385-398. 
Kirschenbaum, H., \& Henderson V. L. (1989). Carl Rogers - dialogues: Conversations with Martin Buber, Paul Tillich, B. F. Skinner, Gregory Bateson, Michael Polanyi, Rollo May, and others. Boston: Houghton Mifflin.

Klassen, R. M., Tze, V. M. C., Betts, S. M., \& Gordon, K. A. (2011). Teacher efficacy research 19982009: Signs of progress of unfulfilled promise? Educational Psychology Review, 23(21), 21-43. doi:10.1007/s10648-010-9141-8

Mareš, J. (2013). Nevhodné chování učitelů k žákům a studentům [Teachers' misbehavior towards pupils and students]. Studia paedagogika, 18(1), 7-36. doi:10.5817/SP2013-1-2

Maršálová, L., \& Mikšík, O. (1990). Metodológia a metódy psychologického výskumu. Bratislava: Slovenské pedagogické nakladatel'stvo.

Midgley, C., Feldlaufer, H., \& Eccles, J. (1989). Change in teacher efficacy and student self- and taskrelated beliefs in mathematics during the transition to junior high school. Journal of Educational Psychology, 81(2), 247-258. doi:10.1037/0022-0663.81.2.247

Milner, H. R., \& Woolfolk Hoy, A. (2003). A case study of an African American teacher's self-efficacy, stereotype threat, and persistence. Teaching and Teacher Education, 19(2), 263-276. doi:10.1016/S0742-051X(02)00099-9

Onafowora, L. L. (2005). Teacher efficacy issues in the practice of novice teachers. Educational Research Quarterly, 28(4), 34-43.

Osgood, C. E. (1975). The measurement of meaning. Urbana: University of Illinois Press.

Pajares, F. (2002). Overview of social cognitive theory and of self-efficacy. University of Kentucky. Retrieved from http://www.des.emory.edu/mfp/eff.html

Průcha, J., Walterová, E., \& Mareš, J. (2009). Pedagogický slovník. Praha: Portál.

Rámcový vzdělávací program pro základní školy. (2013, September 1). Ministry of Education, Youth and Sports (MEYS). Retrieved from http://www.msmt.cz/vzdelavani/zakladnivzdelavani/ucebni-dokumenty

Ross, J. A. (1992). Teacher efficacy and the effect of coaching on student achievement. Canadian Journal of Education, 17(1), 51-65. doi:10.2307/1495395

Ross, J. A. (1994). The impact of an inservice to promote cooperative learning on the stability of teacher efficacy. Teaching and Teacher Education, 10(4), 381-394. doi:10.1016/0742051X(94)90020-5

Ross, J. A., \& Bruce, C. D. (2007). Teacher self-assessment: A mechanism for facilitating professional growth. Teaching and Teacher Education, 23(2), 146-159. doi:10.1016/j.tate.2006.04.035

Rovný př́stup ke vzdělávání v České republice: Situace a doporučení. (2014, February 28). Czech School Inspectorate. Retrieved from http://www.csicr.cz/Prave-menu/Mezinarodnisetreni/Prekonavani-skolniho-neuspechu/Rovny-pristup-ke-vzdelavani-v-CR-situace-a-doporu

Rutter, M. (1990). Psychosocial resilience and protective mechanisms. In J. Rolf, A. S. Masten, D. Cicchetti, K. H. Nuechterlein, \& S. Weintraub (Eds.), Risk and Protective Factors in the Development of Psychopathology (pp. 181-214). Cambridge: Cambridge University press. doi:10.1017/cbo9780511752872.013

Šafránková, A., \& Kocourková, V. (2013a). Analysis of the teachers' attitudes and needs in relation to socially disadvantaged pupils in the Czech Republic. Pedagogika.sk, 4(2), 144-159.

Šafránková, A., \& Kocourková, V. (2013b). The teacher's role in the reflection of social disadvantage. e-Pedagogium, 4, 7-23. 
SocioFaktor, s.r.o. (2013). Sociodemografická analýza: Mapy rozložení ohrožení dětí a rodin v ČR. Ministry of Labour and Social Affairs (MoLSA). Retrieved from http://www.mpsv.cz/files/clanky/15675/SOCDEM_ANALYZA_OHROZENE_DETI.pdf

Soodak, L. C., Podell, D. M., \& Lehman, L. R. (1998). Teacher, student, and school attributes as predictors of teachers' responses to inclusion. The Journal of Special Education, 31(4), 480-97. doi:10.1177/002246699803100405

Starý, K., Dvořák, D., Greger, D., \& Duschinská, K. (2012). Profesní rozvoj učitelů: Podpora učitelů pro zlepšování výsledků žáků. Praha: Karolinum.

Strategie vzdělávací politiky České republiky do roku 2010. (2014, July 9). Ministry of Education, Youth and Sports (MEYS). Retrieved from http://www.vzdelavani2020.cz/

Tedeschi, R. G., \& Calhoun, L. G. (1995). Trauma and transformation: Growing in the aftermath of suffering. Thousand Oaks: Sage.

Tschannen-Moran, M., Woolfolk Hoy, A., \& Hoy, W. K. (1998). Teacher efficacy: Its meaning and measure. Review of Educational Research, 68(2), 202-248. doi:10.3102/00346543068002202

Watters, J. J., \& Ginns, I. S. (1995, April 22-25). Origins of, and changes in preservice teachers_science teaching efficacy. CORE. Retrieved from https://core.ac.uk/download/pdf/10873890.pdf

Weisel A, \& Dror O. (2006). School climate, sense of efficacy and Israeli teachers' attitudes toward inclusion of students with special needs. Education, Citizenship and Social Justice, 1(2), 15774. doi:10.1177/1746197906064677

Wertheim, CH., \& Leyser, Y. (2002). Efficacy beliefs, background variables, and differentiated instruction of Israeli prospective teachers. The Journal of Educational Research, 96(1), 54-63. doi:10.1080/00220670209598791

Webb, R., \& Ashton, P. T. (1987). Teachers' motivation and the conditions of teaching: A call for ecological reform. In S. Walker, \& L. Barton (Eds.), Changing policies, changing teachers: New directions for schooling? (pp. 22-40). Philadelphia: Open University Press. 